\title{
PLCB4 wt Allele
}

National Cancer Institute

\section{Source}

National Cancer Institute. PLCB4 wt Allele. NCI Thesaurus. Code C160885.

Human PLCB4 wild-type allele is located within 20p12.3-p12.2 and is approximately 412 $\mathrm{kb}$ in length. This allele, which encodes 1-phosphatidylinositol 4,5-bisphosphate phosphodiesterase beta-4 protein, plays a role in diacylglycerol (DAG) and inositol 1,4,5trisphosphate (IP3) synthesis. Mutation of the gene is associated with auriculocondylar syndrome 2. 